\title{
Thinking about Religion, Law, and Politics in Latin America*
}

\section{Elizabeth Shakman Hurd*}

Received date: February 28, 2014

Acceptance date: June 10, 2014

Modification date: September 02, 2014

DOI: http://dx.doi.org/10.7440/res51.2015.02

\begin{abstract}
Charles Taylor's A Secular Age is both important and insufficient to the study of religion, law, and politics in Latin America. While aspects of the North Atlantic experience of secularity have become globalized, shaping legal systems and other forms of collective governance around the world, local and regional histories and experiences often depart significantly from Taylor's account of secularity and conception of religion. Scholars of religion and politics in the region need to consider those aspects of local and regional history, such as indigenous and Afro-descendent histories and experiences, that challenge or may be indifferent to globalized Euro-American experiences of secularity and religion. To do so requires grappling with the global effects of the history charted by Taylor while also moving beyond it to account for practices, histories, and ways of life that work outside or against "secularity 3 " and the presumptions about religion that it presupposes and produces.
\end{abstract}

\section{KEY WORDS}

Secularism, religion, law, Latin America, Inter-American Court of Human Rights, Charles Taylor.

\section{Pensar la religión, el derecho y la política en América Latina}

\section{RESUMEN}

La era secular de Charles Taylor es a un mismo tiempo importante e insuficiente para el estudio de la religión, el derecho y la política en América Latina. Si bien hay aspectos de la experiencia del Atlántico Norte que se han globalizado, dando forma a sistemas jurídicos y otras formas de gobernanza política alrededor del mundo, las historias y experiencias locales y regionales suelen distar significativamente de la explicación de la secularidad y la concepción de la religión de Taylor. Los estudios académicos sobre religión y la política en la región necesitan tomar en consideración aquellos aspectos de la historia local y regional, tales como las historias y experiencias indígenas y afro-descendientes, que desafían o pueden ser indiferentes para las experiencias de secularidad y religión euro-americanas y globalizadas. Hacer esto requiere forcejear con los efectos globales de la historia establecidos por Taylor y avanzar al mismo tiempo más allá de ellos para dar cuenta de las prácticas, historias, y formas de vida que operan por fuera o en contra de la "secularidad 3", y las presunciones sobre la religión que aquella presupone y produce.

\section{PALABRAS CLAVE}

Secularismo, religión, ley, América Latina, Corte Interamericana de Derechos Humanos, Charles Taylor.

* Parts of this article appeared in a May 2014 entry of mine on the Social Science Research Council's online discussion forum, The Immanent Frame, which is cited in the bibliography. (Title: "The Specific Order of Difficulty of Religion.") There is no external financing for this work, or other acknowledgement needed.

* Ph.D. in Political Science from Johns Hopkins University (United States). Associate Professor of Political Science, with a courtesy appointment in Religious Studies at Northwestern University (United States). Professor Hurd studies religion, law, and politics in global context, US foreign relations, human rights, and the politics of the Middle East. She is the author of The Politics of Secularism in International Relations (Princeton, 2008), which won an APSA award for the best book on religion and politics (2008-2010). Hurd's current book, Beyond Religious Freedom: The New Global Politics of Religion, will be published by Princeton in 2015. She is co-editor of Politics of Religious Freedom (University of Chicago, 2015), a Symposium on "ReThinking Religious Freedom" in the Journal of Law and Religion (Sept./Oct. 2014), and Comparative Secularisms in a Global Age (Palgrave, 2013). Hurd is co-organizer of Politics of Religious Freedom: Contested Norms and Local Practices, funded by the Luce Foundation. She consults on academic, media, and foundation projects involving religion and international affairs, and has co-edited a series on the politics of religious freedom on The Immanent Frame. Email: eshurd@northwestern.edu 


\section{Pensar a religião, o direito e a política na América Latina}

\section{RESUMO}

A era secular, de Charles Taylor, é ao mesmo tempo importante e insuficiente para o estudo da religião, do direito e da política na América Latina. Embora haja aspectos da experiência do Atlântico Norte que têm sido globalizados, dando forma a sistemas jurídicos e outras formas de governança política ao redor do mundo, as histórias e experiências locais e regionais costumam estar distanciadas da explicação da secularidade e da concepção da religião de Taylor. Os estudos acadêmicos sobre religião e política na região precisam considerar aqueles aspectos da história local e regional, tais como as histórias e experiências indígenas e afrodescendentes, que desafiam ou podem ser indiferentes para as experiências de secularidade e religião euro-americanas e globalizadas. Fazer isso requer forcejar com os efeitos globais da história estabelecidos por Taylor e avançar ao mesmo tempo para mais além deles para dar conta das práticas, histórias e formas de vida que operam por fora ou contra a "secularidade 3", e as presunções sobre a religião que aquela pressupõe e produz.

PALAVRAS-CHAVE

Secularismo, religião, lei, América Latina, Corte Interamericana de Direitos Humanos, Charles Taylor.

Modernity in the south is not adequately understood as a derivative or a doppelganger, a callow copy or a counterfeit, of the EuroAmerican 'original.' To the contrary: it demands to be apprehended and addressed in its own right.

(Jean Comaroff and John L. Comaroff 2013)

\section{Introduction}

$\mathrm{n}$ an essay on equality and citizenship in a multireligious Sudan, Noah Salomon describes the commitment of international development experts to equality before the law as a non-ideological solution to the problems plaguing post-conflict societies. Salomon cites Thomas Carothers of the Carnegie Endowment as an example of the consensus that if the law is procedurally sound, it will serve as an apolitical, technical solution that is distinct from rule by force. Interestingly, Salomon disagrees with Carothers, suggesting that "law, the institutions which promote it, and our relationship to them enfold deep ideological and political commitments which require a whole host of presumptions about justice and how best to achieve it" (Salomon 2011, 201). While the international rule of law is often assumed to govern from a neutral public space that has transcended ideological and political particularities, the hegemony of the rule of law discourse is not itself a mark of neutrality. ${ }^{1}$ It would be a mistake to remove the rule

1 Winnifred Sullivan expands on this point: "the desirability of global extension of the rule of law is currently being promoted by political actors across the ideological spectrum. At times, rhetorical evocation of the rule of law takes on a transcendent glow - as of an of law from conversations about power, history, difference, and governance.The same may be said of secularism. Following a raft of scholarship on secularism and secularity, it is now unsustainable to claim that a clean break has been achieved, anywhere, between secular law and politics on the one hand, and religion on the other. It is now a commonplace for scholars to begin with the assumption that, as Nandini Chatterjee (2010, 537) explains, "state secularism does not imply the withdrawal of the state from religious matters, but on the contrary it consists of the state assuming the role of the ultimate regulator of religious affiliations and arbiter of religious claims." Contemporary practices of religious governance may not be as far removed from the early modern European settlements as secularization theory would suggest. ${ }^{2}$ Scholars working in different national contexts have shown rather that claims to secularism cannot be disentangled from specific histories, laws, and the construal and management of religion as a matter of difference and governance. Inquiry

entire philosophy and practice sufficient for the peaceful coexistence of men on earth: universal law as the successor, one might say, to universal religion. This is a somewhat startling image for those of us who are lawyers - or who study law - and find it as violent, as historically messy, and as genealogically compromised as any other human institution. Yet the rule of law as the very essence of the secular, the a-cultural, the a-political, continues to operate in many places as a stand-in for the last best hope of mankind" $(2010,107)$.

2 Rather than privatizing religion, the early modern settlements inaugurated a new mode of managing it by territorializing religion in separate confessional states, as José Casanova explains: "In the early absolutist phase every state and church in Europe tried to reproduce the model of Christendom according to the principle cuius regio eius religio, which de facto meant that all the territorial national churches fell under the caesaro-papist control of the absolutist state" (Casanova 2001, 424-428). 
into different modes of governing religion by state institutions and the broader socio-legal contexts that sustain and subvert them - many of which have been described as secular- has led to what Nilüfer Göle (2010, 43) describes as "an unpacking of secularity as a religionfree, neutral, and universal development of European modernity." My work on the politics of secularism in international relations was part of this effort to de-center the universal pretensions of claims to secular governance (Hurd 2008a). Nonetheless, even as this approach has taken hold to varying degrees across disciplines, its implications for Latin America have yet to be fully explored.

This article considers, in two steps, how such a research program might be conceived. It begins with an introduction to Charles Taylor's account of the emergence of exclusive humanism in Europe in $A$ Secular Age. Taylor steps outside of the familiar selfpresentation of secularism as a form of governance that emerges naturally once religion has been privatized, marginalized or superseded. As Bonnie Honig observes, and as Taylor shows, "the universal is never really as we imagine it: truly unconditional, context-transcending, and unmarked by particularity and politics" (Honig 2006, 116). Claims to the secular are contingent and context-bound, and marked by particularity and politics, in Europe as elsewhere. ${ }^{3}$ Provincializing North Atlantic moral order as Taylor does suggests that the experience of what he describes as a "closed spin" on the immanent frame does not signal the achievement of secular legal or political neutrality "after" religion. It is, rather, a specific historical and cultural formation emerging from European Christendom that was, to varying degrees, imposed, transformed, ignored and rejected in other parts of the world.

Taylor's account is both important and insufficient to the study of the intersection of religion, law, and politics in Latin America. It is important because through colonialism and globalization, aspects of the North Atlantic experience of secularity have shaped political and religious lives, subjectivities, and forms of collective

3 There is a vast literature on this subject. Markus Dressler and Arvind Mandair have described three trajectories in the critique of secularity: "(i) the socio-political philosophy of liberal secularism exemplified by Charles Taylor (and to some extent shared by thinkers such as John Rawls and Jürgen Habermas); (ii) the 'postmodernist' critiques of onto-theological metaphysics by radical theologians and continental philosophers that have helped to revive the discourse of 'political theology'; (iii) following the work of Michel Foucault and Edward Said, the various forms of discourse analysis focusing on genealogies of power most closely identified with the work of Talal Asad" (Dressler and Mandair 2011, 4). governance all over the world, including Latin America. It is insufficient in that Latin American histories and experiences - in fact, all histories and experiences - also depart in significant ways from Taylor's phenomenology of western secularity. As Cécile Laborde has observed, "the concept [religion] may well have been forged in the crucible of missionary and colonial encounters, but its meanings and uses have further proliferated in non-colonial and post-colonial settings, in ways that escaped, distorted, and subverted the original discourse" (Laborde 2014). It is incumbent on scholars to account for the effects of the legal and political globalization of the North Atlantic history and experience described by Taylor while also creating spaces for local, regional, and global processes and histories that work outside of or may be indifferent to its terms and presumptions. I return to this below.Scholars of religion and politics in Latin America should also resist appropriating secularism or secularity as descriptive categories, inquiring into whether and to what degree states and societies are secularist, religious, undergoing de-secularization, or becoming post-secular. This limits the kinds of questions that can be asked. As John Bowen explains, "when scholars do try to analyze the issues in terms of the very terms of debate, they usually do so as part of their efforts to advance particular policy positions: for or against school prayer, headscarves, or faith-based charities. Precisely because the historical trajectories producing current regimes also produced their ideologies, prominent ways of speaking about state and religion cannot serve as bases for analyzing state and religion" (Bowen 2010, 688). ${ }^{4}$ To move beyond the limitations of adopting as foundational the very terms that need to be subjected to critical and contextual analysis requires asking a different set of questions. It requires, as Dressler and Mandair have suggested, releasing "the space of the political from the grasp of the secularization doctrine" (Dressler and Mandair 2011, 18).What this entails in practical terms, in Latin America or elsewhere, is one of the most interesting and vexing challenges facing scholars of religion and politics today. Various possibilities have been proposed. One is to open the field of inquiry onto a broader social and

4 Bowen continues: "If all we knew were the supposedly general properties and features of "the secular," we would be able to understand very little about how the French governance regime came to be what it is today. Nor, mutatis mutandis, would we be any closer to understanding any other country's particular set of historical processes and modes of governance, including the United States, where the configurations of Catholic immigrants and Protestant traditions of schooling, for example, produced a specific set of tensions focused on Bible reading and individual prayer that do not play as prominent a role elsewhere." 
interpretive field of religion, law, and other collective tools of governance (Hurd 2014). Such an approach would not inquire into the definitions of secularism or religion, comparative typologies of secularism, or how religion has been or should be related to secular law and politics -implicitly, whether religion or some proxy for it should be accommodated legally, and if so, how and with what justification. It would instead focus on how histories and processes such as the globalization of European secularity have shaped local modes of collective governance while at the same time considering aspects of local and regional experience such as, in the case of Latin America, the role of indigenous and Afro-descendent religions that may challenge, be indifferent to, or work outside of Euro-American histories and experiences. Such an approach would toggle back and forth between the local and the transnational, neither assigning totalizing, transformative power to external agents and forms of knowledge nor reducing local or indigenous agency and ways of life to "callow copies or counterfeits" or derivatives of allegedly more robust Euro-American "originals." This returns us to the Comaroffs' remark cited in the epigraph above and requires a different approach to religion, as discussed below.Much has been written about A Secular Age. My intention in what follows is to give a brief synopsis of Taylor's contribution to provincializing European secularity. The idea is to incorporate an awareness of the global impact of the North Atlantic history that Taylor charts, while remaining alert to the local and regional processes and histories that work outside of or against the terms of "secularity 3 " and the presumptions about religion that it enfolds. The predicament of the K'iche' people of Guatemala, discussed below, is one example. There are many others. Provincializing European Secularity

For Taylor, life in a secular age means that many individuals in the West find themselves in some version of what he describes as the "immanent frame," a social space and way of being in the world in which time is secular, instrumental rationality is a key value, and a supernatural or transcendent order is felt by many to be a fading, implausible, and embattled alterative in a world dominated by a particular understanding of immanence. Borrowing from Wittgenstein, Taylor sets out to explain how this frame came to "hold us captive" as modern subjects, showing that particular conditions of belief and unbelief emerged out of European social and religious history and experience. It is this gradual, and in Taylor's view inexorable, process that is chronicled in A Secular Age. In explaining how it became possible for many Europeans and their religious and cultural descendants "to experience moral fullness, to identify the locus of our highest moral capacity and inspiration, without reference to God, but within the range of purely intra-human powers," 5 Taylor offers a rich history of the background conditions against which claims to have "outgrown" religion came to seem natural and normal to many Europeans, and, ultimately, to many others as well. It is a context in which, in Taylor's accounting, moral and spiritual resources are felt to be purely immanent, meaning that they make no reference to "something higher which humans should reverence or love or acknowledge" (Taylor 2007, 244-245). Once myth and error are dissipated, in this view, an empiricalscientific approach to knowledge claims, individualism, negative freedom, and instrumental rationality are positioned to become dominant. As Taylor describes it, "the empirical approach is the only way of acquiring knowledge, and this becomes evident as soon as we free ourselves from the thraldom of a false metaphysics... individualism is the normal fruit of human self-regard absent the illusory claims of God, the Chain of Being, or the sacred order of society" (Taylor 2007, 571).

Taylor proposes an alternative to such "subtraction stories" of modernity, in which superstition and belief are understood to have withered on the vine, opening the way for modern science and humanism to flourish uninhibited by metaphysical constraints. He argues that subtraction stories read out of the picture the possibility that Western modernity is itself powered by a novel form of moral self-understanding which represents one vision of the good among others, rather than the only viable set left after the old myths and legends have been exploded (Taylor 2007, 571). A Secular Age is a phenomenology of the creation and discovery of these new moral sources and the emergence of "secularity 3," a modern context of understanding in which belief and unbelief coexist uneasily, in which one believes or refuses to believe in God, a "crosspressured" condition in which according to Taylor, "our experience of and search for fullness occurs" (Taylor 2007, 19). Secularity 3 is distinguished from the

5 Taylor (2007, 244-245). Taylor cites two preconditions for the emergence of exclusive humanism: the fading of the enchanted world, and the development of a conception of our highest spiritual and moral aspirations "such that we could conceive of doing without God in acknowledging and pursing them," which he attributes to an ethic of imposed order which "made it seem possible to rely exclusively on intra-human powers to carry it through." The result, and the key to the emergence of the immanent frame, is that "the points at which God seemed an indispensable source for this ordering power were the ones which began to fade and become invisible. The hitherto unthought became thinkable" (2007, 234). 
retreat of religion in public life ("secularity 1") and the falling off of individual religious belief and practice ("secularity 2").Diverging from conventional as well as from more critical accounts of secularization, A Secular Age advances a third position which emphasizes the intimacies between Western experiences of secularity and Christianity while defending the emergence of exclusive humanism as "a novel form of moral selfunderstanding, not definable simply by the negation of what preceded it" (Taylor 2007, 571). The hallmark of this new humanism is its attempt to "immanentize" the capacity of benevolence, thus retaining the "agapêanalogue," or the recognition that the power to create a modern order of mutual benefit resides in all and each of us" (Taylor 2007, 247-248). In this account, the "secular" is a slippery term in a shifting secular/other dyad that, just as it seems to have gained a cultural foothold, undergoes another transformation. Initially referring to two dimensions of existence identified by the kind of time essential to each (secular or sacred), this internal dyad mutated into quite another, in which the secular served as an anchor referring to that pertaining to a self-sufficient immanent sphere, as contrasted with a "religious" transcendent realm. From the $17^{\text {th }}$ century onwards, another crucial transformation occurred with a denial of this transcendent level and the emergence of an external dyad in which the secular is denominated as "real" and the religious or transcendent is denominated as "invented." The secular, at that moment, refers to those institutions required to live in this world, while the religious refers to a series of optional extras that are seen by many as thwarting progress in this world. The secular becomes "all there is." This third moment is closed to transcendence, or more accurately, to Taylor's conception of radical transcendence. This is what he refers to as the "declaration of independence" of the immanent. This particular "spin" toward closure, or belief in a purely self-sufficing humanism, is Taylor's attempt to explain and parochialize "the sensed context in which we develop our beliefs," which "has usually sunk to the level of such an unchallenged framework, something we have trouble often thinking ourselves outside of, even as an imaginative exercise" (Taylor 2007, 549-550). In this account, particular transformations in the European social imaginary led to the possibility of the emergence of a self-sufficient immanent sphere that could represent itself as standing apart from, and, for many, sloughing off its transcendent counterpart entirely. Immanence and transcendence are understood and experienced (this goes beyond cognition) in a particular fashion, if only, in many instances, to renounce the possibility of radical transcendence altogether.
Understanding these transformations as one set of possibilities among others - provincializing the history of this particular experience of North Atlantic moral order -helps us to situate the "immanent frame" in a particular European, and then global, history. ${ }^{6}$ This is important for a region such as Latin America in which this history has played a formative role through colonialism, Christian missions, and other historical processes. Yet Taylor's account also remains tethered to very particular understandings of European religious history and experience, and indebted to it in complex ways (Hurd 2008b), that may ultimately limit our field of vision in thinking about the study of religion and politics in this region. Kristina Stoeckl (2014) refers to this in a piece on The Immanent Frame in which she observes that Taylor, John Rawls, and Jürgen Habermas are all "steeped in specific traditions of theological (or religious philosophical) thought" which, though not surprising or even necessarily problematic, remain "mostly implicit in their political theoretical 'operationalization' of religion." To take the next step beyond Taylor's phenomenology of Western secular history and experience requires contemplating the limits of his "operationalization" of religion by, among other things, accounting for histories and experiences that push against, work outside of, or may be entirely indifferent to "secularity 3" and the conceptions of religion that it presupposes and produces. This opens up spaces for work on religion, law, and governance that would otherwise be foreclosed on in accounts that remain wedded to the categories of religious and secular experience and traditions of religious philosophical thought privileged by Taylor and many of his interlocutors.

There are a number of different ways in which to pursue this research agenda. One is to explore the gap between religion as construed for reasons of power -including the law - and a broader field of religious practices of

6 A history that is neither Christian nor post-Christian. The term "post-Christian" raises interesting questions. Former Archbishop of Canterbury Rowan Williams made some interesting observations on the subject recently in reference to the UK: "If I say that this is a postChristian nation, that doesn't mean necessarily non-Christian. It means the cultural memory is still quite strongly Christian. And in some ways, the cultural presence is still quite strongly Christian. But it is post-Christian in the sense that habitual practice for most of the population is not taken for granted." Andrew Sparrow reports that when pressed for a yes/no response to the question about whether Britain was a Christian country, Williams replied: "A Christian country as a nation of believers? No. A Christian country in the sense of still being very much saturated by this vision of the world and shaped by it? Yes" (Sparrow 2014). 
individuals and communities on the ground.7 The next section takes up this possibility by contrasting the legal construction of religion at the Inter-American Court of Human Rights (IACHR) with the experiences of the K'iche' people of Guatemala. Legal Religion in Latin America

The institutionalization of particular conceptions of religion in regional and international legal instruments creates a gap between the forms of religion protected in law and the religious practices of ordinary people. While this is not unique to Latin America, it is particularly visible there in the case of indigenous and Afro-descendent religions, which are less likely to qualify as eligible for protection under legal regimes that privilege an understanding of religion in which Christianity or other monotheistic traditions are taken as normative. To see these dynamics requires accounting for both the socio-legal force of particular understandings of religion (in Martti Koskienniemi's words, "What hierarchies and distributive choices are involved? Who is supposed to be competent to represent the universal?"), ${ }^{8}$ while also accounting for local and regional histories that reject, work outside of, or may be indifferent to them. This section explores the potential of this two-step approach, beginning with the example of a legal case originating in Chile and involving a conflict between freedom of religion and freedom of expression staged within the terms of majoritarian understandings of religion, before moving to a conflict in Guatemala staged outside of those confines. In the process, it seeks to explore the gap between the understanding of religion as belief or conscience reflected in the religion jurisprudence of the Inter-American Court of Human Rights, and a more diverse and multiform field of local histories, practices, and modes of collective being and belonging.

7 This approach to the study of religion, law, and politics is developed further in Hurd (2015).

8 "Law's power and attraction lie in its offering what appears a universal point of view, its ability to raise mere opinions onto a status of what is (universally) right... And yet this universal standpoint constantly eludes us. Rules show themselves as mere interpretations, principles are challenged by equally powerful counter principles, etc. Even as claims about the law of force clash... such claims are nevertheless united in their claiming a universal standpoint. Or to put this in another way, by recourse to law, the contestants agree that only a universal standpoint provides an acceptable basis for the exercise of institutional power (in this case, the use of force) and thus the appropriate standards from which to hold it accountable. This particularity of the law... might have led Brunnée and Toope, to examine what different types of 'universal' are being invoked in the arguments concerning the use of force today. What hierarchies and distributive choices are involved? Who is supposed to be competent to represent the universal? Behind the conventional law on the use of force, there is a whole world order, a system of empowering some and disempowering other institutions and dividing resources between human groups" (Koskienniemi 2011, 324).
In 2001, the IACHR, based in San José, Costa Rica, heard a religious censorship case brought by the InterAmerican Commission on Human Rights against the state of Chile (Inter-American Court of Human Rights 2001). ${ }^{9}$ The case involved a challenge to the refusal of the Chilean Cinematographic Classification Council (CCC) to allow the exhibition of the Martin Scorsese film "The Last Temptation of Christ." The film portrays the story of Jesus but also, as Gomes explains, "departs significantly from the rendition of the Gospels" in portraying Jesus as an ordinary human struggling with guilt and sexual temptation (Gomes 2009, 599). The CCC had originally authorized the exhibition of the Last Temptation film for "mature audiences" only (defined as viewers over age 18) in November 1996. A year later, the Santiago Court of Appeals annulled that decision in response to a remedy for protection filed by seven plaintiffs who alleged that the film was offensive to the figure of Jesus Christ, the Catholic Church, and themselves. In 1997 the Chilean Supreme Court upheld the Court of Appeals' decision to censor the film on the grounds that it presented a "deformed and abused" image of Jesus Christ that endangered the nation by disregarding "the values on which it is based" (IACHR 2001, 30). At this point, a new set of plaintiffs accused the Chilean government of having violated their right to freedom of religion and expression in censoring the exhibition of the film. When their case was brought before the Inter-American Commission, the Commission recommended that the Chilean government suspend censorship of the film and adopt internal legislation to guarantee the enjoyment of the rights and freedom guaranteed by the Convention, observing that the censorship was incompatible with the norms of the IACHR and violated Art. 12 (freedom of religion) and Art. 13 (freedom of expression or thought) of the Convention. ${ }^{10}$ The Chilean Government refused to accept the Commission's recommendation, and so the Commission brought the case to the IACHR in San José to decide whether there had been violations of Articles 12 or 13 of the American Convention. In 2001, the IACHR ruled that Chile had violated the right to freedom of expression and thought embodied in Art. 13, concluding that "state interference affected those who have beliefs related to the religious content of the film 'The Last Temptation of Christ,' because they are prevented from

9 See Alter 2014 on the scope and powers of international courts such as the IACHR and the implications of this emergent international judicial architecture for domestic politics and international relations.

10 On the specific demands made by the Commission in Report No. 69/98 see Gomes (2009, 575). 
exercising the right to freedom of conscience by not being able to see the film and form their own opinion about the ideas expressed in it. Moreover, it affects those who belong to other creeds or who do not have religious convictions, because one creed is privileged in prejudice to the free access to information of other persons, who have the right to access to and form their own opinion about the work" (IACHR 2001, 28). The Court declared, however, that Chile had not violated the right to freedom of conscience and religion embodied in Article 12 because "the prohibition of the exhibition of the film did not impair or deprive anyone of their right to maintain, change, profess or disseminate their religion or beliefs with total freedom." The Court pressured the Chilean government to reform domestic laws regarding freedom of thought and expression, and in 2003 it declared the Chilean government in full compliance with the judgment.

The Last Temptation controversy unfolded within and reproduced particular understandings of freedom of conscience, religion, and expression that would be familiar to anyone following the recent religion jurisprudence of the European Court of Human Rights. According to Benedetto Conforti, the San José judges were directly influenced in their decision by the European Court's freedom of expression jurisprudence (Conforti 2002, 283). The Last Temptation controversy may be situated within a broader context of understanding in which particular experiences of belief and unbelief serve as the baseline for defining and legally protecting freedom of religion. In this sense, one could speak of the globalization of a Taylorian political and legal secularity and sensibility.

It is not, however, shared universally. Consider the experience of the K'iche' people of Cuatemala, represented by the K'iche' People's Council, who in recent years have been subjected to the consequences of ongoing collusion between multinational mining corporations, the police, and the Guatemalan state, which has led to discrimination and violence against them, including massive violations of their cultural heritage and land rights. Journalist and advocate Dianne Post describes their predicament:

In one Mayan area, the K'iche' People's Council is led by Lolita Chávez Ixcaquic, who is also protected by precautionary measures because of an attempted assassination. The council represents 87 Mayan communities that, in a very democratic process, unanimously rejected mining and hydroelectric projects. The foreign commercial companies have offered to pay them a higher percent of profits, failing completely to understand that the reason these projects were rejected is not monetary, but is linked to the refusal to allow destruction of the earth for religious and cultural reasons. (Post 2013)

The K'iche' are a Mayan group living in the western highlands of Guatemala. Rigoberta Menchú, who won the Nobel Peace Price in 1992 for her activism on behalf of indigenous peoples, is perhaps the most well known K'iche'. As scholars of indigenous religion have pointed out in other contexts (Johnson 2007; Wenger 2009), K'iche' attachment to the land does not register legally as religious, thus making it difficult or impossible for the K'iche' to avail themselves of national or international legal protections for religion, religious rights, or religious freedom. Their claims are invisible to organizations, actors and legal instruments focused on the legal realization of religious freedom, because, in some important sense, they are perceived as having no (recognizable) religion. Cast in terms of religion understood as the right to believe or not believe, along the lines of Arts. 12 and 13 of the American Convention, violations of K'iche' religious-cultural heritage are inaudible before the IACHR and Guatemalan authorities. The same holds true for the U.S. State Department. The 2012 State Department International Religious Freedom Report for Guatemala observes that there were "no reports of abuses of religious freedom" in the country. This non-recognition policy unfolds in spite of the fact that the K'iche' have been associated with the most studied indigenous document of Mesoamerica, the Popol Vuh, described by Néstor Quiroa as "a mythicalhistorical narrative that recounts the creation of the universe, followed by the creation of the K'iche' people of highland Guatemala and the legendary history of the K'iche' dynasties up to the arrival of the Spanish in 1524" (Quiroa 2011, 468). Quiroa shows that the Popol Vuh as we know it today is itself "the product of a colonial encounter between Maya and European civilization" (Quiroa 2011, 472), and he concludes that Fr. Francisco Ximénez's treatise should be understood as "an expression of the Dominican evangelization campaign at the beginning of the eighteenth century-a tool intended to destroy native religion in order to replace it with European Christianity" (Quiroa 2011, 479).

Recognition of the significance of the Popol Vuh and K'iche' claims to the land as authentically "religious" might, in the short term, allow the K'iche' to declare themselves a persecuted minority, avail themselves of the law, and address some of the problems attending 
their alleged misrecognition. Yet regardless of how religion is defined and "managed," relying on the category of religion in law means that some groups will be disadvantaged and others privileged. Protections for religions and religious rights guaranteed in law are always partial, reflecting and privileging majoritarian conceptions of religion and majoritarian understandings of rights. In this case, matters are further complicated by the fact that the most influential factor in this controversy is not the law but a range of powerful interests that have stacked the deck against the K'iche' People's Council in favor of neoliberal actors and constituencies that benefit economically from opening the Guatemalan state to transnational capital.

The predicament of the K'iche' People's Council suggests that scholars of religion and politics in Latin America would do well to see beyond the legal and political construal of religion by those in power, including the law, the Guatemalan state, the IACHR and the U.S. State Department, to account for a broader field of sociabilities and historical practice. This would involve, among other steps, attempting to understand indigenous practices and histories on their own terms, even, or especially to the extent that they appear unintelligible or illegible to EuroAmerican legal and normative conceptions of secularity and religion. This would shift our attention away from a focus on separation versus accommodation, freedom versus public order, and religion as the right to believe or not believe, on display in the Last Temptation controversy. It would resist the pressure for normative closure that often nips at the heels of these legal controversies. Most importantly, it would allow us to see that although the K'iche' can legally believe whatever they choose-they may enjoy "religious freedom" under somelegal definition or another - they cannot keep the mining companies off their (sacred) lands. It is important to document these limitations of contemporary legal attempts to guarantee religious freedom at a moment in which protections for (always particular) understandings of religious freedom are gaining traction not only in national and comparative constitutional debates but internationally as well (Hurd 2015). Among other consequences, a commitment to these goods and goals diverts scarce resources and directs international attention away from the needs and demands of indigenous and immigrant communities in Latin America and elsewhere.

That these dynamics are not unique to Latin America is suggestive of the comparative and crossregional potential of this research agenda. Tensions between "official," "governed" or "legal" religion and unsanctioned, multiform "lived" religiosities (Hurd 2015) are also evident in China, where the government has four categories of religious groups: officially sanctioned religions, unregistered groups, "cults," and "feudal superstitions." Officially recognized religions include Buddhism, Catholicism, Daoism, Islam, and Protestantism. A government-controlled religious association oversees each of these official religions as prescribed in the 2005 Religious Affairs Regulations, yet only about 140 million of the more than 200 million religious adherents in China belong to registered religious groups (Carlson 2005, 771). ${ }^{11}$

No rights or protections are accorded to those falling into one or more of the other three categories, which include unregistered groups, cults, and feudal superstitions. Like the K'iche' in Guatemala, "millions of others ascribe to folk religious practices not neatly categorized into traditional Western notions of religion" (Dean, cited in Carlson 2005, 772-773). Before 2005, according to Eric Carlson, "folk religious practices"-or everything that failed to conform to the government's categories of official religion - could exist in a kind of "no-man's land," operating with the tacit consent of local officials (Carlson 2005, 772). The new 2005 regulations, however, eliminated these gray areas, making it more difficult for the State Administration for Religious Affairs to accommodate groups failing to meet the criteria for government registration. This intensification of state oversight meant that new legal tools to crack down on dissidents deemed to be in violation of the regulations became available to national, provincial, and local officials. "Folk" or other forms of religious practice were classified as unorthodox and subjected to heightened state regulation and suppression. As Carlson concludes, "if the new regulations (and the constitution) protect only 'normal' religious activity, then the definition of 'normal' is critical" (Carlson 2005, 772, 767). Interestingly, particularly in light of Guatemala's alleged lack of religious freedom violations, Chinese authorities were quick to claim that the 2005 Regulations complied with international standards on the right to religious freedom. In a speech at the issuance of the regulations, the president of the Daoist Association of China, Zhang Jiyu, assured his audience that the regulations would bring domestic laws into conformity with international

11 Examples of unregistered religions include the underground Catholic Church, Falun Gong, Zhong Gong, worshipers of the Dragon King or God of Fortune, Hinduism, Judaism, various Orthodox churches, a variety of Christian sects, Seventh-Day Adventists, Jehovah's Witnesses, and The Church of Jesus Christ of Latter-Day Saints. 
norms on religion and human rights, stating that, "the religious freedom described in the regulations is exactly in line with the spirit of the United Nations' human rights convention" (Cited in Carlson 2005, 747).

\section{Normative Diversity, Law, and Governance}

The instability of the category of religion as it relates to law and other tools of collective governance, and the myriad entanglements between secular law and other normative systems, have received considerable scholarly attention in recent years (Sullivan, Yelle and TaussigRubbo 2011). More than a decade ago, law and religion scholar Winnifred Sullivan observed that, “'religion' cannot be understood apart from an understanding of the cluster of ideas around the invention and regulation of modern religion, including religious freedom, disestablishment, and the separation of church and state...” (2003,173). Citing Michael Rosenfeld, Sullivan has suggested that "the 'return' of religion takes place in a space structured and conditioned by law - secular law, the 'rule of law,' a law that enjoys an unprecedented hegemony. The vaunted 'freedom' of religion is bounded, and in a very particular way" (2007, 153-154). Hussein Agrama has explored the Egyptian state's authority to define the spaces and sensibilities that are appropriate to religion, suggesting that this authority is often vested in courts, codes, constitutions and judicial authority (Agrama 2010, 504). Malika Zeghal (2008) has charted the Moroccan state's efforts to shape Moroccan Islam through the agency of the monarchy's control of state legal, political, social and economic institutions. John Comaroff has described law's rising global salience "as ideology, as species of practice, as utopic cure-all, as landscape of political struggle, as instrument of governmentality” (Comaroff 2010, 194).

An emerging body of scholarship at the intersection of the study of law, religion, and politics is distinguished by its approach to religion as part of an evolving, shifting series of broader fields of contemporary and historical practice, rather than as a factor that can be singled out from or reduced to other aspects of human activity. Religion is interwoven with and participates in broader fields of historical, institutional, political, economic, and social practice. It is impossible to adopt a singular, trans-historical and transcultural conception of religion given the vast, diverse, and shifting array of practices and histories that fall under the heading of religion as the term is used today. To define groups politically as "religious" actors based on the assumption that something called religion motivates their actions is a questionable move. As C. S. Adcock has shown in her work on India, and as I have suggested with respect to the K'iche' of Guatemala in this article, we need to consider "what is foregrounded when we speak of religion and what forms of politics our talk of religion might exclude" (Adcock 2012). ${ }^{12}$ Working out how to define what religion means for law, as Julian Rivers suggests, "is inevitably, in part, an evaluative process in which the law defines 'religion' for the relevant purposes" (Rivers 2010, vii). Every attempt to legally distinguish between religion and non-religion, believers and non-believers, relies on assumptions about what counts as religion and what does not. Every attempt to protect religion as belief or unbelief requires discriminating between that which counts as religious belief as opposed to other forms of belief or mere opinions (Asad 2012; Sherwood 2015). ${ }^{13}$ As Pamela Slotte explains, "when something is denoted 'religion' or 'religious,' certain things are ascribed to it and it is ascribed a place in society" (Slotte 2010, 3).

And yet, many scholars and practitioners, particularly in the social sciences and policy circles, cling intuitively to a fixed and stable notion of religion as a private set of interiorized beliefs and values independently chosen by individuals, and then enacted. Sullivan describes this as "a stripped-down understanding of religion that finds its origin in Protestant and Enlightenment theories of the state and of religion -one that sees religion's role as one of teaching virtue to its citizens through the training of private consciences-and which often simply refuses to acknowledge cultural aspects of religious life" (Sullivan 1999). It is the religion of a particular version of modern liberalism. A shift in focus away from secularism and secularization as orienting constructs and toward a broader field of interactions between modern religiosities and projects of collective

12 Adcock (2012) has observed that scholars of India have often taken recourse to a "religious" vocabulary to describe vernacular idioms of politics that are outside the civic arena, thereby obscuring "the labor of translation that was required when Indian actors represented their political struggles before the state." This move renders invisible the politics of caste, while emphasizing a politics of religious difference focused on the right (or not) to proselytize, heightening tensions surrounding the politics of religious conversion.

13 "The difficulty is this: What are to count as religious beliefs? Should beliefs denounced by the medieval Latin church as superstitio (wrongheadedness) therefore be regarded as secular beliefs? Or should they be pronounced religious on the criteria provided by lateEnlightenment critics for whom all religion was superstition? Is the intention to carry out a particular act always crucial to its religiosity? If so, how and by whom is that to be judged?" Asad $(2012,46)$. 
governance will help to parochialize the stillpowerful conception of religion as "private, voluntary, individual, textual, and believed" that underlies many academic discussions, drawing attention instead to the "religion of most of the world," which is public, oral, enacted, and communal (Sullivan 2007, 8). This approach to religion, law, and politics would open spaces in which to explore life worlds that are situated outside, at the margins of, or beyond the terms and understandings inherited - and at times imposed- by those immersed in one "spin" or another of Taylor's immanent frame. It would take as a point of departure the cultural peculiarities and historical contingencies of legal subjectivities that are indebted to the North Atlantic understandings of religion, secularity, and subjectivity described by Taylor. It would highlight the gap between religion as construed by the church, state, or court for reasons of power, and religion as lived and experienced by individuals and groups with complex and changing relations to the institutions and hierarchies that allegedly represent them, from which they have fallen away, or to which they never fully subscribed (Hurd 2015).

In the chapter mentioned in the introduction to this article, Noah Salomon describes the worldviews of the various groups that he encountered during his fieldwork in Sudan, including members of the government and allied Islamists (al-haraka al-islaamiyya, al-islaamiyuun), evangelist Salafis, and politically engaged Sufis. He explains that one of his objectives in describing their divergent worldviews is to make it possible to begin to "imagine a conversation about interreligious coexistence which does not rely on the liberal categories bequeathed by international human rights discourse... this is not a language of human rights (or even "the rights of non-Muslims"), but rather one in which the specificity of each religious category is recognized and engaged with in a manner appropriate to each kind" (Salomon 2011, 214). One challenge for scholars of religion and politics in Latin America, and elsewhere, is to develop frameworks that are open to the potential of such conversations. This involves reconsidering, without discarding, the assumptions about religion that underlie current legal and constitutional debates and inform international human rights advocacy. It involves resisting attempts to assimilate other ways of being and belonging - from the K'iche' to the Sufis to practitioners of chinese "folk" religion-into legal and normative frameworks indebted to particular, though powerful, European and American experiences of secularity and conceptions of religious freedom. ••

\section{References}

1. Adcock, C. S. 2012. The Problem of Translation: A View from India. The Immanent Frame. <http://blogs.ssrc.org/ tif/2012/o4/26/the-problem-of-translation-a-viewfrom-india/>.

2. Agrama, Hussein Ali. 2010. Secularism, Sovereignty, Indeterminacy: Is Egypt a Secular or a Religious State? Comparative Studies in Society and History $52, \mathrm{n}^{\circ} 3$ : 495-523.

3. Alter, Karen J. 2014. The New Terrain of International Law: Courts, Politics, Rights. Princeton: Princeton University Press.

4. Asad, Talal. 2012. Thinking about Religious Belief and Politics. In The Cambridge Companion to Religious Studies, ed. Robert Orsi. Cambridge: Cambridge University Press, 36-57.

5. Bowen, John. 2010. Secularism: Conceptual Genealogy or Political Dilemma? Comparative Studies in Society and History 52, $\mathrm{n}^{\circ}$ 3: 680-694.

6. Carlson, Eric. 2005. China's New Regulations on Religion: A Small Step, Not a Great Leap, Forward. BYU Law Review 3: 747-798.

7. Casanova, José. 2001. Religion, the New Millennium, and Globalization. Sociology of Religion 62, $\mathrm{n}^{\circ}$ 4: 415-441.

8. Chatterjee, Nandini. 2010. English Law, Brahmo Marriage, and the Problem of Religious Difference: Civil Marriage Laws in Britain and India. Comparative Studies in Society and History 52, $\mathrm{n}^{\circ}$ 3: 524-552.

9. Comaroff, Jean and John L. Comaroff. 2013. Writing Theory from the South: The Global Order from an African Perspective. World Financial Review 17-20.

10. Comaroff, John L. 2010. Reflections on the Rise of Legal Theology: Law and Religion in the Twenty-First Century. In Contemporary Religiosities: Emergent Socialities and the PostNation-State, eds. Bruce Kapferer, Kari Tell, and Annelin Eriksen. New York: Berghahn Books, 193-216.

11. Conforti, Benedetto. 2002. La Tutela Internazionale della Libertà Religiosa. Rivista Internazionale dei Diritti dell'Uomo $\mathrm{XV}, \mathrm{n}^{\circ}$ 2: 269-283.

12. Dressler, Markus and Arvind-Pal S. Mandair. 2011. Introduction: Modernity, Religion-Making, and the Postsecular. In Secularism and Religion-Making, eds. Markus Dressler and Arvind Mandair. Oxford: Oxford University Press, 3-36.

13. Göle, Nilüfer. 2010. Manifestations of the Religious-Secular Divide: Self, State and the Public Sphere. In Comparative Secularisms in a Clobal Age, eds. Linell E. Cady and Elizabeth Shakman Hurd. New York: Palgrave Macmillan, 41-56.

14. Gomes, Evaldo Xavier. 2009. The Implementation of Inter-American Norms on Freedom of Religion in the National Legislation of OAS Member States. Brigham Young University Law Review 3: 575-596.

15. Honig, Bonnie. 2006. Another Cosmopolitanism? Law and Politics in the New Europe. In Seyla Benhabib, Another 
Cosmopolitanism, The Berkeley Tanner Lectures, Robert Post, eds. with commentaries by Jeremy Waldron, Bonnie Honig, and Will Kymlicka. Oxford: Oxford University Press, 102-27.

16. Hurd, Elizabeth Shakman. 2008a. The Politics of Secularism in International Relations. Princeton: Princeton University Press.

17. Hurd, Elizabeth Shakman. 2008b. Book Review: A Secular Age by Charles Taylor. Political Theory 36, $n^{\circ}$ 3: 486-491.

18. Hurd, Elizabeth Shakman. 2014. The Specific Order of Difficulty of Religion. The Immanent Frame. <http://bit. ly/1kqYQnG>.

19. Hurd, Elizabeth Shakman. 2015. Beyond Religious Freedom: The New Global Politics of Religion. Princeton: Princeton University Press.

20. Inter-American Court of Human Rights (IACHR). 2001. Case of "The Last Temptation of Christ," (Olmedo Bustos et al.) vs. Chile. Judgment of February 5. <http://www.corteidh. or.cr/docs/casos/articulos/seriec_73_ing.pdf>.

21. Johnson, Greg. 2007. Sacred Claims: Repatriation and Living Tradition. Charlottesville: University of Virginia Press.

22. Koskienniemi, Martti. 2011. The Mystery of Legal Obligation. International Theory $3, \mathrm{n}^{\circ} 2$, 319-325.

23. Laborde, Cécile. 2014. Three Approaches to the Study of Religion. The Immanent Frame. <http://blogs.ssrc.org/tif/2014/o2/o5/ three-approaches-to-the-study-of-religion/>.

24. Post, Dianne. 2013. Land, Life, and Honor: Guatemala's Women in Resistance. Fair Observer. <http://www.fairobserver.com/ article/land-life-honor-guatemala-women-resistance>.

25. Quiroa, Néstor. 2011. The Popol Vuh and the Dominican Religious Extirpation in Highland Guatemala: Prologues and Annotations of Fr. Francisco Ximénez. The Americas $67, n^{\circ} 4: 467-494$.

26. Rivers, Julian. 2010. The Law of Organized Religions: Between Establishment and Secularism. Oxford: Oxford University Press.

27. Salomon, Noah. 2011. The Ruse of Law: Legal Equality and the Problem of Citizenship in a Multi-religious Sudan. In After Secular Law, eds. Winnifred Fallers Sullivan, Robert A. Yelle, and Mateo Taussig-Rubbo. Stanford: Stanford University Press, 200-220.
28. Sherwood, Yvonne. 2015. On the Freedom of the Concepts of Religion and Belief. In Politics of Religious Freedom, eds. Winnifred Fallers Sullivan, Elizabeth Shakman Hurd, Saba Mahmood, and Peter Danchin. Chicago: University of Chicago Press.

29. Slotte, Pamela. 2010. The Religious and the Secular in European Human Rights Discourse. Finnish Yearbook of International Law 21: 1-56.

30. Sparrow, Andrew. 2014. Britain Is Now 'Post-Christian', Says Ex-Archbishop Rowan Williams. The Guardian. <http:// www.theguardian.com/uk-news/2014/apr/27/britainpost-christian-says-rowan-williams>.

31. Stoeckl, Kristina. 2014. The Theology Blind Spot. The Immanent Frame. <http://blogs.ssrc.org/ tif/2014/o2/13/the-theology-blind-spot/>.

32. Sullivan, Winnifred Fallers. 1999. Exporting Religion: Where the Religious Freedom Act Fails. Commonweal 126, $n^{\circ} 4: 10-11$.

33. Sullivan, Winnifred Fallers. 2003. Religious Freedom and the Rule of Law: Exporting Modernity in a Postmodern World? Mississippi College Law Review 22, $\mathrm{n}^{\circ}$ 2: 173-184.

34. Sullivan, Winnifred Fallers. 2007. The Impossibility of Religious Freedom. Princeton: Princeton University Press.

35. Sullivan, Winnifred Fallers. 2010. Varieties of Legal Secularism. In Comparative Secularisms in a Clobal Age, eds. Linell E. Cady and Elizabeth Shakman Hurd. New York: Palgrave, 107-120.

36. Sullivan, Winnifred Fallers, Robert A. Yelle and Mateo Taussig-Rubbo (eds.). 2011. After Secular Law.Stanford: Stanford University Press.

37. Taylor, Charles. 2007. A Secular Age. Harvard: Belknap.

38. Wenger, Tisa. 2009. We Have a Religion: The 1920s Pueblo Indian Dance Controversy and American Religious Freedom. Chapel Hill: The University of North Carolina Press.

39. Zeghal, Malika. 2008. Islamism in Morocco: Religion, Authoritarianism and Electoral Politics. Princeton: Markus Wiener Publishers. 